\title{
A Policy Analysis of Professional Certification for the Vocational High School Graduates: The Case Study
}

\author{
Nuphanudin ${ }^{1}$, Sugiarto ${ }^{2}$, Supadi ${ }^{3}$ \\ \{nuphanudin@mahasiswa.unj.ac.id ${ }^{1}$, sugiarto@unj.ac.id ${ }^{2}$, supadi@unj.ac.id ${ }^{3}$ \} \\ Universitas Negeri Jakarta, Indonesia
}

\begin{abstract}
The aim of this research was to analyze the policy implementation of professional certification for vocational high school graduates in the Professional Certification Institution of State Vocational High School (SMK Negeri) 7 Bandung. This was conducted through the use of a qualitative method by applying the Context, Input, Process, Product (CIPP) model. Primary data was obtained through interview and observation, while secondary data were taken from official documents. The analysis conducted revealed that 1) the purpose of certification is welldefined, well-understood, and well-operated; 2) planning and the allocation of resources were classified accordingly; 3 ) the process of certification followed the guidelines of Certification Authority; 4) in work, competency should be preserved, not only once, but for a long time. The certification was quite effective in achieving the goals of ensuring and preserving competencies gained from either formal or informal learning process, internship or work experience.
\end{abstract}

Keywords: Vocational Education, competency-based assessment, revitalization

\section{Introduction}

Presidential Instruction Number 9 of 2016 concerning the Vocational High School (VHS) Revitalization was given in order to increase the quality and competitiveness of Indonesian Human Resources by starting Vocational Education in the country. This was directed towards welcoming the big waves of Industry 4.0 era [1], [2]. To be competitive in this era, there is a need for a creative, innovative, skilled and specialist workforce [3], [4], [6].

A nation's competitiveness [9] is measured by the quality of its Human Resources and job competency. One of the efforts made at increasing these in Vocational High School was by giving competency certificate to the graduates through a professional certification institution [2]. This gives them the opportunity of getting jobs that match their skills and also make them more competitive in the international labor market [11]. Therefore, the purpose of professional certification is to give recognition to competent Indonesian workers based on competence, professionalism, and competitiveness [12].

The certification guarantees that a Vocational High School graduate has the competence needed by the industry [3]. It also serves as a means of branding for them, such that, any of them with the 
certificate can easily get a job in the industry. In order to get the certification, VHS's students were made to join the workplace assessment [13] in Lembaga Sertifikasi Profesi Pihak Satu (LSP P1) or Professional Certification Institute (PCI) $1^{\text {st }}$ Party.

LSP/PCI is an institution of professional certification licensed by Certification Authority, acknowledged as Badan Nasional Sertifikasi Profesi (BNSP) or National Body of Professional Certification (NBPC) in Indonesia. It is responsible for the improvement of competency standard, provision of assessment service and professional competency certification. Therefore, PCI/LSP's major role is to ensure and preserve competency. It was established to fulfill a mandate of Government Regulation Number 23 of 2004. Generally, the national standard system can be described as follows:

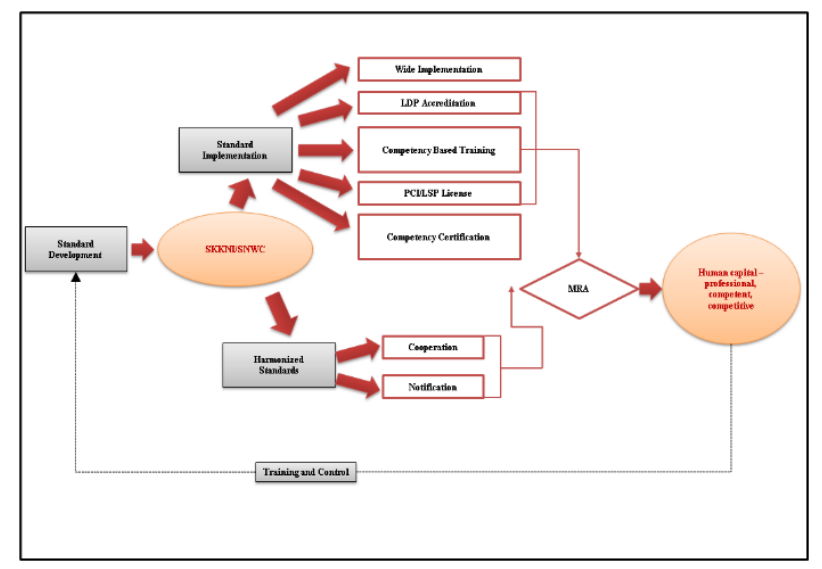

Fig 1. Standard System of National Work Competency

Based on BNSP/NBPC Regulation Number 2/BNSP/III/2014 about Guidelines for Establishing Professional Certification Institutions, LSP/PCI is divided into 4, which are 1) PCI $1^{\text {st }}$ Party industry, established by the industry to assess and certify its own employees during their period of employment; 2) PCI $1^{\text {st }}$ Party Vocational School, established by the vocational or professional school to certify its own students during their learning process in the school/institution; 3) PCI $2^{\text {nd }}$ Party, built up by industry to certify its supplier or a competent authority in the matter of doing obligatory certification to its policy network; and 4) PCI $3^{\text {rd }}$ Party, built up by industrial and professional associations supposedly supported by its competent authority.

The PCI/LSP that meets these requirements shall be licensed by BNSP after accreditation process. A licensed PCI/LSP should preserve its program and organizational merit and do supervision/surveillance to maintain its aptness and competence. 


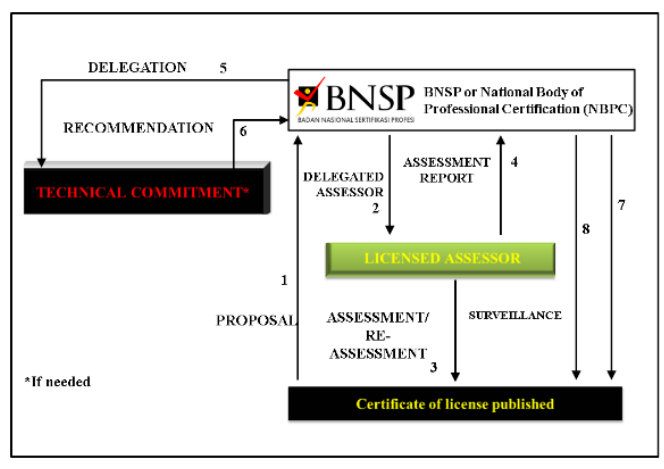

Fig 2. Process of PCI/LSP License

Professional certification which is known as the work competency certification by Vocational High School Graduates is a public policy that has been in existence after the Laws Number 13 of 2003 about Employment and strengthened by Presidential Instruction Number 9 of 2016, therefore, there is a need for evaluation of its implementation process. ISO Standard 9001: 2000 [15] states that "certification refers to the issuing of written assurance (the certificate) by an independent external body that it has audited a management system and verified that it conforms to the requirements specified in the standard". This means the certification is carried out by an independent external institute after it has confirmed that an individual or an organization has met with the terms and conditions required by the management of the regulatory body.

In another literature, a license is described to be "the legal process of permitting a person to practice a trade or profession once he or she has met certification standards" [16]. It is a legal process that allows someone to practice their profession after they have already satisfied the standard needed for certification. In agreement with this, Nguyen reveals that "certification is the process of deciding that an individual meets the minimum standards of competence in a profession" [16]. This shows that an individual can only be certified for a job if he or she has already met the minimum competency standard. Wallage also came up with the explanation that "the awarding of a certificate confirms achievement in an examination of course of study" [17]. This reveals that apart from the fact that it is been used in certifying the competence of an individual it is also used to show that a person has completed a course of study or is successful in an examination.

Certification is a public policy because it is created by the government to solve the education problem in order to produce quality and competent graduates. However, public policy is defined to be [18]: "a course of government action (or inaction) taken in response to social problems. Social problems are conditions the public widely perceives to be unacceptable and therefore requiring intervention". This means that public policies are created and implemented by the government through their agencies and departments to solve societal problems.

LSP/PCI of the State Vocational High School (SMK Negeri) 7 Bandung was licensed by the BNSP on $21^{\text {st }}$ September 2015 to make the process of getting the Independent Work Competency Certification Process Level II faster but empirical data showed that the professional certification policy implementation has not been able to fulfill the purpose for which it was created. Therefore, 
this research was conducted in order to know if the policy has been able to increase the quality of Vocational High School Graduates as well as their chances of getting jobs easily in the industry.

\section{Method of Research}

This study was conducted at SMK Negeri 7 Bandung, West Java Province between March 18November 27, 2018. This location was selected because of its authority to carry out professional certification to improve the quality of vocational graduates and has been designated as a Referral Vocational School through the Decree of the Director of Vocational High School Development Directorate General of Primary and Secondary Education under the Ministry of Education and Culture Number 003/D5.6/KP/2018. Research datasets can be accessed through https://osf.io/6gqtw/.

This study was conducted qualitatively through the application of the CIPP (Context, Input, Process, Product) model [19]. This can be applied in various fields such as education, management, companies and so on as well as in various levels of policies, projects, and programs [19]. It was developed by Stufflebeam at Ohio State University and has been widely applied in many research works. The four components of CIPP are used as evaluation objectives. The model views programs as being evaluated as a system. Thus, evaluating a program requires analyzing it based on its components.

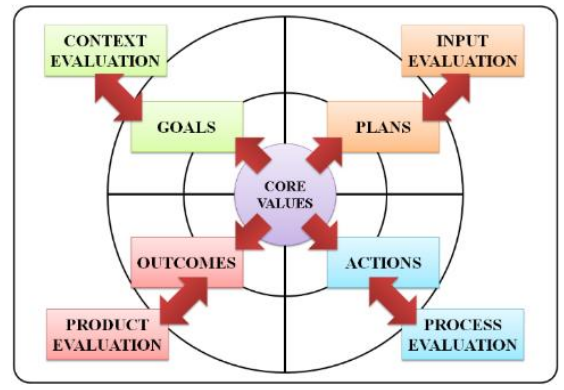

Fig 3. The Key Components of the CIPP Evaluation Model

Stufflebeam argues that the key components of the CIPP evaluation model and its relationship with the program are described in concentric circles [19] as presented in Figure 3. The circle shows the core values and the circle around it is divided into four evaluative focuses relating to other programs or businesses: goals, plans, actions, and results. The outer circle shows the type of evaluation, each of which functions for four focuses, namely context, input, process, and product. Whereas, the two-way arrow shows a reciprocal relationship between the evaluative focus and the type of evaluation.

The model is linear, so evaluations are carried out sequentially, considering the components evaluated are interrelated. That is, evaluation of input must be preceded by that of the context, evaluation of the process must be preceded by that of input, while evaluation of the product must be 
preceded by that of the process. The CIPP model is a dynamic system with a holistic approach aimed at providing a detailed and broad description of a program, from the context to its implementation. It allows for improvements during the program, provides final information and makes provision for a good basis on which decisions, policies, and subsequent program delivery can be made. So, it was considered suitable for evaluating professional certification programs for vocational high school graduates and also in finding out the effectiveness of successful program achievements. The results of this evaluation can be used by stakeholders in decision-making processes.

Context evaluation relates to the goals, objectives and basic aspects of program preparation. Input evaluation is related to organizational support such as the aspects of organizational structure, implementation procedures, funding, and government support. Process evaluation has to do with the suitability of the objectives and implementation, understanding by the beneficiaries, use of budget, and the supervision and transparency of the program implementation. Product evaluation looks at the results of implementing a professional certification program.

\section{Results and Discussion}

The data were obtained through in-depth interviews, documentation studies, and direct observation. The main instrument of the study is the researcher while the key informants are the people involved in the implementation of professional certification in SMKN 7 Bandung. They were determined based on their authority, activity, knowledge, and mastery of the program. The program evaluation instruments were developed by identifying aspects to be evaluated which were majorly based on problems in the field. The interview was structured to include questions regarding the implementation of professional certification for graduates of vocational high schools with respect to components of context, input, process, and products.

The professional certification program already exists and has been implemented, the CIPP model was more comprehensive and effective in describing, obtaining, and presenting information that is very useful in assessing alternative decisions as regards the sustainability of the program. Therefore, the evaluation as not carried out to prove the existence of the program but to improve it.

The professional certification program evaluation design based on the CIPP model is as shown in the following Figure 4.

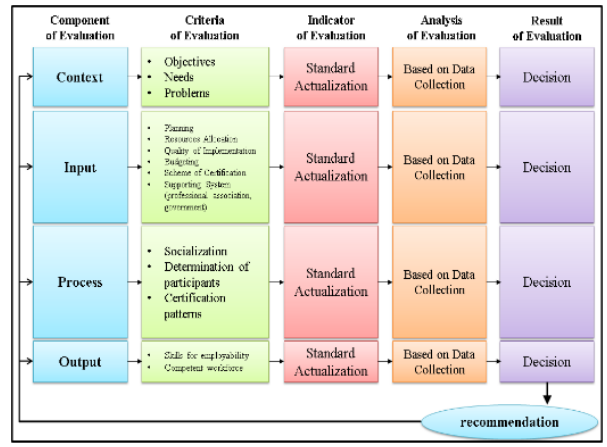


Fig 4. Design of Professional Certification Evaluation Based on CIPP Model

This method involved giving a rating of good or bad and succeed or fail with respect to the program performance. For the sake of objectivity, the assessment process emphasized the importance of ethics and reliability approach. In this evaluation, there was collection and analysis of information which was used to make recommendations to LSP SMKN 7 Bandung about the strategy they can use in the future when implementing professional certification for vocational high school graduates.

Data observed were validated based on the submission of Yin [22] that "data analysis consists of examining, categorizing, tabulating, testing, or otherwise recombining both quantitative and qualitative evidence to address initial propositions of a study". This was done by testing the truth data, classifying data as sub focus, placing the data in a matrix or table and drawing a conclusion from the database. It is, therefore, important to state that data truth was checked by using different triangulation sources such as the method, theory, and investigator triangulation.

The competency test was supervised and assessed directly by a licensed assessor with a competency assessor certificate from BNSP while the Competency Test Materials (Materi Uji Kompetensi) was prepared based on certification schemes or competency standards according to the Indonesian National Qualification Framework (KKNI). After the competency test was conducted, the assessor submitted a recommendation to the Professional Certification Institution as a material consideration to make a decision whether the assertion is declared Competent or Not Competent. Participants that were declared competent were given a Competency Certificate. Through this, graduates have the right to receive awards and deserve to provide services or work according to their professional competence. Meanwhile, those that were declared 'Not Competent', can take the competency test again in the following year.

The professional certification for vocational high school graduates already has a clear juridical format, limited time, clearly defined, operationalized, and understood by LSP SMKN 7 Bandung and it was stated to have been formulated "to reinforce one's competence, certification of the profession as evidence, so not only pass and get a diploma from school, later to facilitate future employment prospects" (Interview, August 2, 2018). Planning and allocation of resources were classified based on resources, budget, time constraints, and work indicator. Overall, it was well documented by strategic planning and fulfilled the evaluation criteria [19].

The process of professional certification in LSP SMKN 7 Bandung started by socialization through the determination of the members, certification method, practice and surveillance of graduates after certification. "The main purpose is to increase the link and match, the second is to improve the quality, so it is expected that later when they're working, it is in accordance with the existing certificate" (Interview, March 26, 2018). For the certification process, three recommendations were given to improve the competency test. These include conformity with the Standard Kompetensi Kerja Nasional Indonesia (SKKNI) or Standard of National Work Competency (SNWC), quality and integrity of the assessor, and industry communication.

Firstly, For assessment needs, BNSP empowered the SKKNI/SNWC to develop a competency package that must be implemented for employees by companies in order to meet the needs of the industry [23]. This can be seen in the development of the Competency Manner Test by the body. The plans and programs of the organization must be suitable for industry 4.0, otherwise, it must be 
revised. This is necessary to make VHS graduates suitable for the labor market because if they are not, they will be rejected even if they have the required certification.

Secondly, the quality and integrity of the assessor are very important when carrying out professional competency tests. The assessor must have two competencies and they include assessment management and integrity. The former ensures that the individual has the required skills to prepare the assessment unit while the latter involves making sure that the assessor conducts the test objectively without showing any favor to the students.

Thirdly, communication and coordination play in major role in the industry [3]. It is important that the industries are made to understand that there VHS graduates with competency certificate as well as the policy that guides their recruitment. This will help in bridging the gap between the graduates and the industry.

The government and LSP should make sure that these recommendations are implemented in all honesty. This will motivate the students to study effectively, thereby, improving their quality and acceptability in industries. If the process is continuous, it will aid the proposed revitalization of VHS in the country.

\section{Conclusion}

"Competence can be trained. Competence is not something that is kept secret. Concerning competence, practice questions should not be kept secret, the theory is yes" (Interview, August 10, 2018). This research showed that industrial workforce competence can be improved through the certification of graduates [23].

The analysis procedure according to Yin [22] revealed that professional certification for Vocational High School Graduates in LSP SMKN 7 Bandung helped in producing competent and competitive graduates. However, the evaluation needs to be continued. "The certificate issued by LSP, when the graduates work according to their competence. For college? No need" (Interview, August 10, 2018). In addition, every effort needs patience and extra energy to get the desired result, therefore, policy implementors must ensure that they exercise patience and input extra energy in achieving the aims and objectives of this policy.

Acknowledgments. Gratitude to Mr. Sugiarto, Mr. Matin, Usep Suhud, Deudeu M, Dadang S., Ikin S., Tatang H., Agus S., Supriatiningsih, Rani P., Ivan A., Ivan I., Achamad N., Nurul, and R.A. Rogayah for their support. I, also appreciate my beloved wife, Mala, and our kids (Dzira, Deefikha, Dziharka) for their support and understanding throughout the period of this research.

\section{References}

[1] M. Trstenjak and P. Cosic, "Process Planning in Industry 4.0 Environment," Procedia Manuf., vol. 11, pp. 1744-1750 (2017)

[2] A. Van der Bijl and M. Lawrence, "Retention and attrition among National Certificate (Vocational) Civil and Construction students in South African TVET," Ind. High. Educ., p. 095042221880064 (2018)

[3] J. Itohan Oviawe, "Bridging Skill Gap to Meet Technical, Vocational Education and Training SchoolWorkplace Collaboration in the 21 \&amp;lt;sup\&amp;gt;st\&amp;lt;/sup\&amp;gt; Century," Int. J. Vocat. 
Educ. Train. Res., vol. 3, no. 1, p. 7 (2017)

[4] P. C. Kyllonen, "Soft Skills for the Workplace," Chang. Mag. High. Learn. (2013)

[6] G. Mulongo, I. Kitururu, and M. Irira, "Determinants for positioning and promoting tvet in Tanzania: Information for developing a marketing strategy," J. Tech. Educ. Train., vol. 8, no. 2 (2016)

[9] A. Adamik and M. Nowicki, "Preparedness of companies for digital transformation and creating a competitive advantage in the age of Industry 4.0," Proc. Int. Conf. Bus. Excell., vol. 12, no. 1, pp. 10-24 (2018) [11] J. E. Edokpolor and R. O. Owenvbiugie, "Technical and vocational education and training skills: An Antidote For Job Creation And Sustainable Development Of Nigerian economy," Probl. Educ. 21 st Century, vol. 75 , no. 6 (2017)

[12] C. R. Ridzwan, S. Malik, Z. Hanapi, S. Mohamed, M. A. Hussain, and S. Shahrudin, "Skills and Knowledge Competency of Technical and Vocational Education and Training Graduate," Asian Soc. Sci., vol. 13, no. 4, p. 69 (2017)

[13] M. J. B. Govaerts, M. W. J. Van de Wiel, L. W. T. Schuwirth, C. P. M. Van der Vleuten, and A. M. M. Muijtjens, "Workplace-based assessment: Raters' performance theories and constructs," Adv. Heal. Sci. Educ (2013)

[14] C. Steinman, R. Deshpande, and J. . Farley, "ISO 9001:2000," J. Acad. Mark. Sci., vol. 28, no. 1, pp. 109-119 (2000)

[17] H. Nguyen, "Teacher Preparation Programs in the United States.," Int. J. Progress. Educ., vol. 14, no. 3, pp. 76-92 (2018)

[18] Oxford Dictionary, "Definition of authentic in English by Oxford Dictionaries," Oxford Dictionary, 2018. [Online]. Available: https://en.oxforddictionaries.com/definition/authentic.

[19] S. R. Kraft, M. E., \& Furlong, "Kraft_Furlong_chapter 4," in Public policy: Politics, analysis, and alternatives, pp. 118-145 (2015)

[20] D. L. Stufflebeam and C. L. S. Coryn, "Daniel Stufflebeam's CIPP model for evaluation: An improvement and accountability oriented approach," in Evaluation theory, models, and applications: Research methods for the social sciences, pp. 309-340 (2014)

[21] T. Aberdeen, "Yin, R. K. (2009). Case study research: Design and methods (4th Ed.). Thousand Oaks, CA: Sage.," Can. J. Action Res., vol. 14, no. 1, pp. 69-71 (2013)

[22] Ikatan Apoteker Indonesia, "Standar Kompetensi Apoteker Indonesia," Standar Kompetensi Apot. Indones., pp. 1-56 (2016.) 